\title{
Review of hospitalized cases of general paralysis of the insane
}

\author{
K. DAWSON-BUTTERWORTH* AND P. R. M. HEATHCOTE† \\ United Sheffield Hospitals
}

Hopes of eradicating neurosyphilis were raised by the introduction of penicillin (Mahoney, Arnold, and Harris, 1943, 1949) but more recently Willcox (1967), in reviewing 25 years of penicillin therapy in venereology, indicated possible evidence of recrudescence, although admitting some beneficial impact (but see Brit. med. F., 1969). It is true that the number of deaths certified as due to GPI has fallen dramatically in Great Britain.

Laird (1962) suggested a decrease in diagnosed cases of GPI and Steel (1960) and Dewhurst (1969) suggested that the presenting features had changed. Similar observations have been made by Joffe, Black, and Floyd (1968), Levy (1968), Heathfield (1968), and Wilner and Brody (1968).

Earlier reports of the relative merits of penicillin, heavy metal, or fever therapy in the treatment of neurosyphilis were confusing. Arendtsen and Welner (1955) and Hahn, Webster, Weickhardt, Thomas, Timberlake, Solomon, Stokes, Moore, Heyman, Gammon, Gleeson, Curtis, and Cutler (1959) found no appreciable difference in clinical status or fitness for work between patients receiving penicillin alone and those receiving penicillin and fever combined. It was concluded that the possible additive effects of the fever therapy were not sufficient to justify its use. A previous study (Hahn, Cutler, Curtis, Gammon, Heyman, Johnwick, Stokes, Solomon, Thomas, Timberlake, Webster, and Gleeson 1956) had indicated that in asymptomatic neurosyphilis 9 per cent. of cases may need re-treatment regardless of the original dose of penicillin, but the cumulative probability of progression to symptomatic neurosyphilis was only 3.31 per cent. 7 years after treatment. Kopp and Raaschou-Nielsen (1956) indicated a mortality rate from fever therapy of 2 per cent. and Tempski, Olszewska, and Heyko-Porebski (1957) found that treatment of neurosyphilis with

Received for publication October 3, 1969

^Formerly Registrar in Psychiatry, Middlewood Hospital, Sheffield 6. †Formerly Research Assistant in Psychiatry, Middlewood Hospital, Sheffield.

Address for reprints: K. D.-B., 247 Carter Knowle Road, Sheffield, S11 9FW, Yorks. penicillin and fever therapy was unsuccessful in 36.8 per cent. of cases. The failure rate for combined therapy was 28 per cent, whereas for penicillin alone it was $41 \cdot 2$ per cent. This suggested a beneficial additive effect of combined therapy.

The results of Orbán and Lazarovits (1956) 5 years' after treatment with fever and/or penicillin showed that 16 per cent. relapsed with penicillin alone and only 2 per cent. after combined penicillin and fever. But patients with signs of posterior column involvement appeared to suffer faster progression of the disease on combined therapy. Malykin, Sokolin, and Vasil'ev (1958) showed improved electro-encephalograms in patients with GPI on antibiotic therapy, those on arsenicals and bismuth preparations showed deterioration in the electro-encephalograms for a time, which was later followed by improvement. Kaplan, Ryan, Thomas, Cutler, and Jenkins (1958) and Kaplan, Ryan, Thomas, Cutler, and Jones (1958) suggested high success rates with arsenicals and bismuth.

Wodniansky (1963), in considering the late results of penicillin treatment of neurosyphilis, suggested that there was no advantage over bismuth and arsenic, and felt that arsenic was not inferior to bismuth. Huriez, Agache, and Souilliart (1962) reported a 15-year study of 617 cases of late visceral syphilis and indicated a rise in the proportion of cases of neurosyphilis. They favoured the use of mercuric cyanide and bismuth in addition to penicillin.

Guthe (1965) indicated that in no studies of syphilitic patients treated with heavy metal therapy had control been as good as when penicillin alone had been used. Thus there are numerous conflicting reports in the literature, but it would seem that most authors favour high doses of penicillin. Fever therapy and arsenicals have largely been abandoned.

The aim of this study was to attempt a detailed investigation of all the available cases of GPI resident in a large psychiatric hospital. Efforts were made to assess the long-term progression of clinical manifestations of the disease and its possible relationship to treatment. 


\section{Material and methods}

The whole population of a psychiatric hospital $(1,845$ persons) was screened in order to identify those suffering from GPI. The case records were carefully searched for all available data on the course of the illness during the stay in hospital. Particular interest was directed towards obtaining the incidence and nature of clinical signs and symptoms at three stages:

(i) On admission.

(ii) Immediately after treatment.

(iii) At the present time (last assessment).

Originally 45 patients were identified. This included as suffering from GPI all cases diagnosed with certainty on admission and additional cases discovered by serological studies and reviews of patients with unusual modes of presentation (formerly diagnosed, for example, as cases of schizophrenia, chronic mania, subnormality, or organic brain damage). From this sub-group some further cases were isolated (some have been considered elsewhere; Dawson-Butterworth, 1967a, 1968, 1969).

The 45 patients thus identified were interviewed individually and physically examined at intervals of one month over a 6 -month period, so as to make a careful reappraisal of the current mental and physical state. These data were then compared with the data recorded at other phases of the illness.

\section{Results}

(a) Of the original 24 males and 21 females identified from the main hospital population as suffering from GPI, one male was rejected because he was suffering from cerebral cysticercosis and one female excluded because insufficient data had been noted in the early history and there was no record of positive serological tests for syphilis. Repeated TPI tests all gave negative results in this last case. There were thus 43 cases of GPI in a population of 1,845 , an incidence of 2.3 per cent. The sex ratio was 23 males to 20 females.

\section{(b) Ages (Table I)}

The age range for men on admission to hospital was 34 to 58 years (mean $44 \cdot 8$ ) and for women 25 to 62 years (mean 42.3). The peak age at onset for both sexes fell within the age range 40 to 50 years.

TA BLE I Age distribution at admission, by sex

\begin{tabular}{|c|c|c|c|}
\hline Age (years) & Males & Females & Total \\
\hline $\begin{array}{l}20-30 \\
30-40 \\
40-50 \\
50-60 \\
60-70\end{array}$ & $\begin{array}{r}0 \\
7 \\
10 \\
6 \\
0\end{array}$ & $\begin{array}{r}3 \\
3 \\
10 \\
2 \\
2\end{array}$ & $\begin{array}{r}3 \\
10 \\
20 \\
8 \\
2\end{array}$ \\
\hline Total & 23 & 20 & 43 \\
\hline
\end{tabular}

\section{(c) Onset (Table II)}

The mean duration of symptoms before admission was $4 \cdot 1$ years for men (range $6 \mathrm{mths}$ to $20 \mathrm{yrs}$ ), and $2 \cdot 1$ years for women (range $6 \mathrm{mths}$ to $20 \mathrm{yrs}$ ). The majority of patients of both sexes had had symptoms for 3 years or less before admission.

TABLE I I Duration of symptoms before admission, by $\operatorname{sex}$

\begin{tabular}{|c|c|c|c|}
\hline Duration (years) & Males & Females & Total \\
\hline $\begin{array}{l}<6 \text { mths } \\
6 \text { mths }-3 \text { yrs } \\
3-5 \\
5-10 \\
10-15 \\
15-20 \\
>20 \\
\text { Unspecified }\end{array}$ & $\begin{array}{l}3 \\
5 \\
2 \\
2 \\
1 \\
0 \\
1 \\
9\end{array}$ & $\begin{array}{l}4 \\
5 \\
1 \\
1 \\
1 \\
0 \\
0 \\
8\end{array}$ & $\begin{array}{r}7 \\
10 \\
3 \\
3 \\
2 \\
0 \\
1 \\
17\end{array}$ \\
\hline Total & 23 & 20 & 43 \\
\hline
\end{tabular}

\section{(d) Occupation}

The male population included two professional workers, two skilled labourers, fifteen labourers, and four unknown. The female population included one professional (nurse), one domestic, two housekeepers, fifteen housewives, and one unknown.

\section{(e) Marital status (Table III)}

TABLE II I Marital status, by sex

\begin{tabular}{|c|c|c|c|}
\hline Status & Males & Females & Total \\
\hline $\begin{array}{l}\text { Married } \\
\text { Single } \\
\text { Separated } \\
\text { Divorced } \\
\text { Widowed } \\
\text { Cohabiting } \\
\text { Unknown }\end{array}$ & $\begin{array}{r}11 \\
5 \\
1 \\
1 \\
1 \\
1 \\
3\end{array}$ & $\begin{array}{r}11 \\
4 \\
1 \\
1 \\
1 \\
2 \\
0\end{array}$ & $\begin{array}{r}22 \\
9 \\
2 \\
2 \\
2 \\
3 \\
3\end{array}$ \\
\hline Total & 23 & 20 & 43 \\
\hline
\end{tabular}

(f) History of contact (Table IV)

T A B L E IV History of contact, by sex of patient

\begin{tabular}{|c|c|c|c|}
\hline History & Males & Females & Total \\
\hline $\begin{array}{l}\text { Unrecorded } \\
\text { From spouse } \\
\text { Congenital } \\
\text { Armed Forces } \\
\text { From consort } \\
\text { Promiscuous }\end{array}$ & $\begin{array}{r}15 \\
0 \\
3 \\
3 \\
0 \\
2\end{array}$ & $\begin{array}{r}15 \\
2 \\
0 \\
1 \\
1 \\
1\end{array}$ & $\begin{array}{r}30 \\
2 \\
3 \\
4 \\
1 \\
3\end{array}$ \\
\hline Total & 23 & 20 & 43 \\
\hline
\end{tabular}

(g) Length of stay in hospital (Table V)

The mean duration of hospitalization for men was 15.5 years (range $6 \mathrm{mths}$ to $20 \mathrm{yrs}$ ) and for women 16.6 years (range $6 \mathrm{mths}$ to $20 \mathrm{yrs}$ ). The majority of 
patients of both sexes had been hospitalized for at least 15 years.

TABLE $\mathrm{V}$ Duration of stay in hospital, by sex

\begin{tabular}{|c|c|c|c|}
\hline Duration (years) & Males & Females & Total \\
\hline$<1$ & 3 & 1 & 4 \\
\hline $1-3$ & 0 & 1 & 1 \\
\hline $3-5$ & 0 & 0 & 0 \\
\hline $5-10$ & 4 & 5 & 9 \\
\hline $10-15$ & 0 & 4 & 4 \\
\hline $15-20$ & 10 & 2 & 12 \\
\hline$>20$ & 6 & 7 & 13 \\
\hline Total & 23 & 20 & 43 \\
\hline
\end{tabular}

(h) Degree of incapacity

Of the 23 men, two were discharged after treatment (these had had symptoms for only 6 months or less before admission), five were capable of work in a sheltered environment, seven were ambulant but not capable of work, and eight were bedridden. Of the 20 women, one was discharged after treatment (symptoms of only 6 mths' duration), two were capable of work in a sheltered environment, thirteen were ambulant but incapable of work, and four were bedridden. Thus, taking males and females together, three ( 7 per cent.) were discharged, seven (17 per cent.) were capable of work, twenty ( 49 per cent.) were ambulant, and twelve (27 per cent.) were bedridden. Those who had only had a short duration of symptoms were still in contact with relatives and friends prepared to support and encourage them on discharge. The hospital involved in this study has an industrial workshop within the grounds which caters for the patients capable of work in a sheltered environment. Had this not been so, some of the patients retained might possibly have been discharged but only to exist in social obscurity and meagre circumstances. The majority of the patients retained in hospital were too deteriorated intellectually or in their personal habits to be accepted by society or were unable to care for themselves.

\section{(i) Signs and symptoms (Table VI)}

These were determined at the three stages mentioned above. It was found that certain symptoms formerly regarded as characteristic of late neurosyphilis occurred only rarely.

These included limb pains, parasthesiae, sexual impotence, tabetic bladder, visual hallucinations, suicide, hoarding of rubbish, paresis of one limb, bilateral ptosis, chorciform movements, visceral crises, perforating ulcers, headaches, 'catastrophic reaction', self-mutilation, vertigo, gummata, bone lesions, confabulation, insomnia, and syncope. One patient had involvement of the right 5 th and 7 th cranial nerves. Only one man had evidence of genital scarring and only one patient practised a form of self-mutilation (reported elsewhere: Dawson-Butterworth, 1967a). One female patient had an isolated episode of severe self-mutilation.

TA B LE VI Percentage incidence of symptoms at three stages of investigation, by sex

\begin{tabular}{|c|c|c|c|c|c|c|c|c|c|}
\hline \multirow{2}{*}{ Symptom } & \multicolumn{3}{|c|}{ On admission } & \multicolumn{3}{|c|}{ After treatment } & \multicolumn{3}{|c|}{ At present time } \\
\hline & $M$ & $F$ & $M+F$ & $M$ & $F$ & $M \multimap F$ & $M$ & $F$ & $M+F$ \\
\hline Dementia & 60.0 & $55^{\circ} 0$ & $55^{\cdot} 0$ & $8 \cdot 7$ & $15 \cdot 0$ & $11 \cdot 6$ & $57 \cdot 0$ & $65 \cdot 0$ & $60 \cdot 0$ \\
\hline Confusion & $87 \cdot 0$ & 70.0 & $79 \cdot 0$ & $4 \cdot 3$ & 0.0 & $2 \cdot 3$ & $83 \cdot 0$ & 65.0 & $74 \cdot 0$ \\
\hline Euphoria & $17 \cdot 5$ & $35 \cdot 0$ & $25 \cdot 0$ & $4 \cdot 3$ & $5 \cdot 0$ & $4 \cdot 6$ & $22 \cdot 0$ & $35 \cdot 0$ & $28 \cdot 0$ \\
\hline Depression & $8 \cdot 7$ & 35.0 & $21 \cdot 0$ & 0.0 & $5 \cdot 0$ & $2 \cdot 3$ & $4 \cdot 3$ & 35.0 & $18 \cdot 6$ \\
\hline Grandiose delusions & $26 \cdot 0$ & $20 \cdot 0$ & $23 \cdot 0$ & $13 \cdot 0$ & $5 \cdot 0$ & $9 \cdot 3$ & $26 \cdot 0$ & $20 \cdot 0$ & $23 \cdot 0$ \\
\hline Paranoid delusions & $26 \cdot 0$ & $25 \cdot 0$ & $25 \cdot 0$ & 0.0 & 0.0 & 0.0 & $17 \cdot 4$ & $25 \cdot 0$ & $21 \cdot 0$ \\
\hline Incontinence & $8 \cdot 7$ & $5 \cdot 0$ & $7 \cdot 0$ & $8 \cdot 7$ & $10 \cdot 0$ & $9 \cdot 3$ & $13 \cdot 0$ & $15 \cdot 0$ & $14 \cdot 0$ \\
\hline Dysarthria & $35 \cdot 0$ & $35 \cdot 0$ & $35 \cdot 0$ & $8 \cdot 7$ & $20 \cdot 0$ & $14 \cdot 0$ & $39 \cdot 0$ & $55 \cdot 0$ & $46 \cdot 5$ \\
\hline Fits & 0.0 & $10 \cdot 0$ & $4 \cdot 6$ & $22 \cdot 0$ & $5 \cdot 0$ & $14 \cdot 0$ & $22 \cdot 0$ & $15 \cdot 0$ & $18 \cdot 6$ \\
\hline Severe psychosis & $52 \cdot 0$ & $50 \cdot 0$ & $52 \cdot 0$ & $52 \cdot 0$ & $50 \cdot 0$ & $50 \cdot 0$ & $52 \cdot 0$ & $50 \cdot 0$ & $51 \cdot 0$ \\
\hline Cardiovascular lesions & $8 \cdot 7$ & $5 \cdot 0$ & $7 \cdot 0$ & $39 \cdot 0$ & $15 \cdot 0$ & $28 \cdot 0$ & $48 \cdot 0$ & 20.0 & $35 \cdot 0$ \\
\hline Tabes alone & $22 \cdot 2$ & $5 \cdot 0$ & $14 \cdot 0$ & $13 \cdot 0$ & $25 \cdot 0$ & $18 \cdot 6$ & $35 \cdot 0$ & $30 \cdot 0$ & $32 \cdot 5$ \\
\hline Optic atrophy & $4 \cdot 3$ & 0.0 & $2 \cdot 3$ & $4 \cdot 3$ & 0.0 & $2 \cdot 3$ & $13 \cdot 0$ & 0.0 & $7 \cdot 0$ \\
\hline Tabes with optic atrophy & $4 \cdot 3$ & 0.0 & $2 \cdot 3$ & $13 \cdot 0$ & 0.0 & $7 \cdot 0$ & $8 \cdot 7$ & 0.0 & $4 \cdot 6$ \\
\hline Argyll Robertson pupils & $35 \cdot 0$ & $35 \cdot 0$ & 35.0 & $31 \cdot 0$ & $25 \cdot 0$ & $28 \cdot 0$ & $52 \cdot 0$ & $60 \cdot 0$ & $56 \cdot 0$ \\
\hline Unequal pupils & $4 \cdot 3$ & 0.0 & $2 \cdot 3$ & $4 \cdot 3$ & $5 \cdot 0$ & $4 \cdot 6$ & $8 \cdot 7$ & $5 \cdot 0$ & $7 \cdot 0$ \\
\hline Sluggish pupils & $15 \cdot 0$ & $20 \cdot 0$ & $16 \cdot 4$ & 0.0 & 0.0 & 0.0 & $13 \cdot 0$ & $20 \cdot 0$ & $16 \cdot 0$ \\
\hline Charcot joints & $4 \cdot 3$ & 0.0 & $2 \cdot 3$ & $4 \cdot 3$ & 0.0 & $2 \cdot 3$ & $8 \cdot 7$ & 0.0 & $4 \cdot 6$ \\
\hline Ataxia & $30 \cdot 0$ & $25 \cdot 0$ & $28 \cdot 0$ & $26 \cdot 0$ & $20 \cdot 0$ & $23 \cdot 0$ & $56 \cdot 0$ & $45 \cdot 0$ & $51 \cdot 0$ \\
\hline Tongue tremors & $13 \cdot 0$ & $5 \cdot 0$ & $9 \cdot 3$ & $4 \cdot 3$ & $5 \cdot 0$ & $4 \cdot 6$ & $17 \cdot 4$ & $10 \cdot 0$ & $14 \cdot 0$ \\
\hline Auditory hallucinations & 13.0 & $10 \cdot 0$ & 11.6 & $13 \cdot 0$ & $5 \cdot 0$ & $9 \cdot 3$ & $26 \cdot 0$ & $15 \cdot 0$ & $21 \cdot 0$ \\
\hline Aggression & $26 \cdot 0$ & $5 \cdot 0$ & $16 \cdot 3$ & 0.0 & 0.0 & 0.0 & $26 \cdot 0$ & $5 \cdot 0$ & $16 \cdot 3$ \\
\hline Emotional liability & $17 \cdot 4$ & $10 \cdot 0$ & $14 \cdot 0$ & 0.0 & $5 \cdot 0$ & $2 \cdot 3$ & $17 \cdot 4$ & $15 \cdot 0$ & $16 \cdot 0$ \\
\hline Mania & $13 \cdot 0$ & 0.0 & $7 \cdot 0$ & 0.0 & 0.0 & 0.0 & $8 \cdot 7$ & 0.0 & $4 \cdot 6$ \\
\hline Perseveration & $4 \cdot 3$ & 0.0 & $2 \cdot 3$ & $8 \cdot 7$ & 0.0 & $4 \cdot 6$ & $13 \cdot 0$ & 0.0 & $7 \cdot 0$ \\
\hline
\end{tabular}

Figures in Table expressed as percentages. Number of cases $M=23, F=20, M+F=43$. 
Both males and females were found to have a high incidence of dementia and confusion on admission (approximately 60 and 80 per cent. respectively). This tended to improve with treatment but showed evidence of return to the original levels after a few years. The incidence of euphoria tended to remain constant over the years, but this symptom was more apparent in females than males. The incidence of depression was also relatively constant but grandiose and paranoid delusions, which had seemed to disappear with treatment, tended to reappear in later years. The proportion of cases with incontinence showed little variation from admission to the present time.

Originally, dysarthria was detected in a little over 30 per cent. of cases and tended to become worse with the passage of time. The incidence of this symptom tended to rise with the duration of hospitalization to 39 per cent. in men and 55 per cent. in women ( 46.5 per cent. for males and females combined). Fits occurred in approximately 20 per cent. of cases. A severe psychosis, with loss of contact with reality, misinterpretation, misidentification, ideas of reference, and body image disturbances, was present throughout the illness in 50 per cent. of cases. An increase in incidence of symptoms and signs affecting the cardiovascular system was noted in both men and women even after treatment. The incidence of tabes with ataxia also showed an apparent rise. The well-documented 'trombone tremor' of the tongue and lips was a constant feature in 15 per cent. of cases. There was a slight increase in auditory hallucinations from 12 to 20 per cent.

On admission, men tended to be more aggressive than women. This uncontrolled behaviour subsided with treatment but tended to recur after a few years in the same proportions as before. Approximately 20 per cent. showed emotional lability throughout the illness. Mania gradually subsided over a period of some years. There was a higher incidence of perseveration in men throughout the course of the illness.

\section{(j) New cases}

The hospital has 1,845 beds serving a population of $1,250,000$. During the 6 months of the study, 435 men and 588 wowsen were admitted, of whom three men and one woman had GPI. None of the 52 male deaths and one of fifty female deaths were due to GPI.

Over 80 percent. of newly admitted patients underwent serum tests for syphilis and this revealed one clinically unsuspected case of GPI; of 900 routine tests performed the useful discovery rate was $0 \cdot 11$ per cent.

\section{(k) Treatment}

\section{PENICILLIN}

Fifteen men (65 per cent.) received therapy with penicillin (dosage range 6-63 m.u., mean 12-15 m.u.); four had two courses and two had three courses.

Eight women ( 40 per cent.) also received penicillin (dosage range 21-84 m.u., mean 11-14 m.u.); three had had several courses of penicillin of which the doses were incompletely recorded in the original case histories; one woman whose disease had shown a relentless worsening had received six courses of penicillin to a total of $84 \mathrm{~m}$.u.

\section{HEAVY METALS}

Six women ( 30 per cent.) were treated with trivalent arsenicals, two (10 per cent.) with pentavalent arsenicals, six (30 per cent.) with bismuth, and two (10 per cent.) with a combination of a mercurial salt with potassium iodide.

Ten men (43.5 per cent.) had trivalent arsenicals, two (8.7 per cent.) pentavalent arsenicals, fourteen (61 per cent.) bismuth, and one ( 4.3 per cent.) a mixture of mercurial salt and potassium iodide.

\section{FEVER THERAPY}

Two women ( 10 per cent.) had been treated with the Kettering hypertherm and seven ( 35 per cent.) had received malarial therapy. One man ( 4.3 per cent.) received hyperthermy and eleven (48 per cent.) had malarial therapy. One of the female patients and three of the males had fever and rigors induced by the injection of a variety of chemical agents including sulphur oil.

\section{ELECTROCONVULSIVE THERAPY (ECT)}

Three men and three women received modified ECT during their stay in hospital. Treatment in each case was given for attacks of otherwise uncontrollable mania and appeared to have the desired calming effect. Two patients who were reported to be 'suicidal' on admission were not given ECT.

\section{(l) Blood studies}

The Wassermann reaction (WR) or earlier versions of complement-fixation blood tests were positive in 100 per cent. of these males and females on admission. Immediately after treatment 90 per cent. were still sero-positive, but during their stay of 10 to 15 years in hospital the percentage had decreased to about 55 per cent.

A study of the development of new central nervous system signs and symptoms (epilepsy, dysarthria, optic atrophy, pupillary changes, retinopathy, in- 
continence, hallucinations, delusions, and lightning pains) revealed that the onset or lack of these new symptoms was unrelated to positive or negative serum test results; e.g. some patients still showing positive tests had no further deterioration whereas others showing a reversal of the serum tests to negative had developed further severe manifestations of disease.

It did not prove possible to assess all cases with the Treponema pallidum immobilization test (TPI) on account of restricted laboratory facilities. In those tested (approximately 40 per cent.) the TPI test was always positive, whether the WR in the blood or CSF had reverted to negative or not. Again, with these cases, some patients showed more rapid and severe deterioration than others.

The numbers of patients receiving penicillin, bismuth, arsenicals, or fever therapy as a single mode of treatment were too small for comparison of their relative efficacy to be significant. Combinations of penicillin with one or more of the other types of treatment did not seem to have any particular advantages over high doses of penicillin alone and even in patients receiving all types of treatment there was a high incidence of the development of new central nervous system signs. The tendency towards seroreversal appeared to be unrelated to any form of treatment.

\section{(m) Cerebrospinal fuid (CSF) investigations}

With both men and women the incidence of positive Wassermann reactions in the cerebrospinal fluid on admission was 85 per cent. ( 17 of 20 ) in women and 87 per cent. (20 of 23 ) in men. Immediately after treatment this fell to 60 per cent. After a period of 10 years in hospital the percentage in this particular series of patients had fallen to zero in men but 20 per cent. ( 4 of 20 ) women still gave positive reactions.

An increase in the CSF cell count was seen in 47.5 per cent. (11 of 23 ) in men and 45 per cent. ( 9 of 20 ) in women on admission. After treatment it fell to 35 per cent. ( 8 of 23) in men and 35 per cent. $(7$ of 20$)$ in women, and at the last assessment had decreased still further to 13 per cent. ( 3 of 23 ) in men and 20 per cent. ( 4 of 20 ) in women.

Increased globulin was detected in the cerebrospinal fluid of 87 per cent. ( 20 of 23 ) in men and 85 per cent. (17 of 20) in women on admission. After treatment the globulin fell to 60 per cent., but there was a sex difference, 0 per cent. in men and 35 per cent. in women at the last assessment, although they had received similar treatment with doses generally accepted to be adequate.

The Lange colloidal gold test showed paretic curves in 61 per cent. of men and 45 per cent. of women on admission. At the last assessment 45 per cent. (11 of 23) men and 40 per cent. ( 8 of 20) women still had paretic Lange curves. 15 per cent. ( 3 of 20) women developed abnormalities in the third zone of the Lange curve after admission. Unfortunately the records of cerebrospinal fluid protein levels at the various stages were largely incomplete but where they were recorded, they tended to approach normal within a few months of the completion of treatment.

As with the blood studies, the characteristics of the cerebrospinal fluid seemed to bear little relationship to the onset of new symptoms after treatment. It could perhaps have been expected that clinical progression would have been more in evidence amongst patients whose cerebrospinal fluid had failed to revert to normal but this was not so; two patients with florid cerebrospinal fluid abnormalities on admission were said to have had no treatment and no information was available from any source, but they progressed in a limited fashion to a stable level, remained capable of work and did not develop any further symptoms. On the other hand some patients receiving combined treatment with penicillin, bismuth, arsenicals, and malarial therapy, continued to show relatively rapid deterioration despite complete reversal of the cerebrospinal fluid characteristics to normal.

\section{Discussion}

Most of the patients in this study had survived more than 15 years after their initial admission to hospital and treatment. Wilner and Brody (1968) studied 100 patients who had survived at least 10 years and found a high rate (39 per cent.) of development of new neurological signs after treatment with penicillin alone or in combination with other types of therapy. Our group of patients also showed a high incidence of new symptoms (i.e. 28 of 43, 65 per cent.) affecting the central nervous system (this figure includes both neurological localizing signs and defects of higher cortical function). It must be remembered that they are a selected group since they had been kept in hospital by the severity of their disease. Unfortunately it was not within the scope of this study to determine the fate of those who had been 'successfully' treated and discharged within the 15 to 20 year period. Thus no definite conclusions could be drawn about the occurrence of fundamental changes in the disease, as suggested by other authors.

Wilner and Brody (1968) did not attempt to evaluate the progression of mental and neurological signs before therapy, whereas our study attempts to show the proportions of symptoms at three definite stages in the illness. If they had included progression 
of pre-existing signs as well as the development of new signs, their percentage of patients showing deterioration would probably have been higher and closer to our findings. They emphasized that their estimates were conservative. Similar observations were made by Ehrentheil and Muench (1959) and these authors also indicated a high death rate.

Hahn and others (1959) indicated that, in patients whose cerebrospinal fluid indicated inactivity and who had already received $6 \mathrm{~m} . u$. penicillin or more without benefit, there was usually failure to improve despite further treatment. They suggested that in such cases the process is advanced but static, and implied that the severity of the psychosis at the time of treatment was of considerable prognostic importance. Wilner and Brody (1968) found no correlation between the size of the dose of penicillin and the onset of new symptoms after treatment.

Our findings tend to agree with the latter and, if the two series are taken together, there seems to be no definite relationship between clinical progression and any kind of therapy, once the disease has become severe enough in its effect to require continued hospitalization. Neither higher drug doses nor combinations of therapies seem to prevent the development of further neurological complications. Also, our findings tend to agree with that of Wilner and Brody that progression of the disease may take place in the absence of reactive CSF tests and that some cases with persistent signs of cerebrospinal fluid activity (as indicated by Dattner, Thomas, and De Mello, 1951, and Dattner, Carmichael, De Mello, and Thomas, 1952) do not necessarily develop fresh symptoms.

Hahn and others (1959) also indicated that clinical progression was unrelated to cerebrospinal fluid activity. Kalz and Scott (1958) and Wilner and Brody (1968) indicated that the appearance of new symptoms affecting the central nervous system may be the result of the neurosyphilitic process progressing further or of an increased susceptibility to other neurological diseases. Henderson and Gillespie (1962) stated that, in untreated cases, periods of apparent return to health (seldom exceeding 2 years) are characteristic. They noted that the earlier the onset of symptoms after the initial infection the more rapidly progressive was the illness, and that the effectiveness of treatment tended to diminish in direct proportion to the duration of symptoms before treatment.

In considering the appearance of new neurological symptoms, the effect of ageing must be taken into consideration. Nevertheless, the development of similar clinical patterns in different patients of different ages (Table VI) strongly suggests that the process was more likely to be related to the disease than to the age. Lewis (1950) attempted to devise a procedure for estimating mental deterioration in patients with neurosyphilis, with the idea of differentiating psychologically between various forms of GPI. An attempt was made in the early phase of our study to carry out detailed psychological assessment of individual patients. The incidence of relatively severe dementia was high and several patients were incapable of taking the more sophisticated tests for brain damage; the findings of the pilot survey were so ill-defined that further studies were abandoned.

Our findings for incidence, sex-ratio, mean age at onset, duration of symptoms before admission, occupation, and mode of first clinical presentation correlated closely with those of Dewhurst (1969). His estimate of the expected annual incidence is $1: 200,000$ population, so that from $1,250,000$ one would expect six to seven new cases a year or three to four every 6 months. Thus the four new cases admitted in 6 months in this present study confirms his expected incidence. In 1917 cases of GPI accounted for 5 to 15 per cent. of all mental hospital admissions.

Dewhurst stated that delusions of grandeur are not now one of the commonest presenting features of cerebral syphilis. He observed them in 10.9 per cent. of his patients, and Bostroem (1930) gave a figure of 10 per cent. In our series 9.3 per cent. of patients had delusions of grandeur initially but this increased to 23.0 per cent. at the last assessment. 18.7 per cent. of Dewhurst's series developed epileptic fits. Varma (1952) gave a figure of 20 per cent. and in our series it was 18.6 per cent. which strongly supports Dewhurst's finding. Dattner and others (1952) noted that a few patients developed epileptic seizures some years after the cerebrospinal fluid tests had indicated that the disease was inactive.

Dewhurst whose cases were not comparable with ours in many respects suggested that the most common presenting feature was depression, but in our series, dementia and confusion were the most prominent features. This agrees with the findings of Power (1930), Hahn and others (1959), and Vurdelja, Vucković, and Kapamadzija (1961). Again the effect of ageing has to be considered but such symptoms were not strictly confined to the oldest patients studied, even some of the youngest rapidly became demented. Dysarthria tended to worsen with the passage of time.

The apparent increase in signs of tabes and cardiovascular involvement (Barnett, 1955) might have been attributed to increased awareness by the doctors, but O'Brien, Smith, and Fisherkeller (1955) and Raaschou-Nielsen and Kopp (1957) have emphasized 
the well-recognized association of cardiovascular syphilis and late neurosyphilis. The finding of 56 per cent. with Argyll Robertson pupils in this series agrees with the 46.3 per cent. reported by Liu (1960).

Of interest in our study was the changing sex incidence of certain features with the passage of time. Thus men had a higher incidence of confusion than women after 10 to 15 years whereas women tended to be more dysarthric and depressed than men. Men had a greater tendency to develop cardiovascular lesions, optic atrophy, auditory hallucinations, aggression, mania, and perseveration than women, but the latter had a higher incidence of abnormalities of the cerebrospinal fluid than men despite comparable treatment. The development of Charcot's arthropathy was confined to men.

Banks (1968) doubted the value of routine screening for syphilis in mental hospitals because the useful discovery rate was only 0.11 per cent., the same as in this series. Nevertheless caution should be exercised before abandoning screening, for eminently treatable cases may be overlooked (Dawson-Butterworth, 1967b; Pritchard, Mechie, McHugh, and Boot, 1967), especially at a time when clinical awareness is likely to be diminished by the scanty opportunities of gaining experience of what was once a more common disease.

All reasonable steps should be taken to lessen the risk of overlooking cases in which something can be done to arrest the progress of deterioration, although there are many in which treatment may have little effect.

What then can be the explanation for the apparent failure of therapy in this selected group of patients who are doomed to long-term hospitalization after the discovery of the GPI?

Certain well recognized factors were doubtless operative in some cases, for example: poor intellectual and employment capacity before the illness, delayed diagnosis and treatment, and a severe psychosis before treatment (Hahn and others, 1959). But there still remains the problem posed by those cases showing a relentless downhill course despite prompt and then repeated courses of penicillin, some with, some without CSF evidence suggesting reactivation of the treponemal infection.

Since publication of the work of Collart, Borel, and Durel (1962a, b, c, 1964) there has been increasing evidence of the persistence after treatment of organisms apparently Treponema pallidum in tissues and intraocular and cerebrospinal fluids in cases of late syphilis. The identity of these treponemal forms, the criteria for judging them Treponema pallidum and the evidence for their continuing virulence are still under debate (Turner, Hardy, and Newman, 1969); furthermore the number of cases of neurosyphilis in which treponemal forms have been found in tissue and CSF is small (Collart, Borel, and Durel, 1962a, b, c, 1964; Smith and Israel, 1968; Gager, Israel, and Smith, 1968). None the less it seems reasonable to raise the possibility that persistence of viable treponemes after treatment may account for the downhill course in certain cases of GPI.

Our investigation showed that in nearly every case requiring continued hospital care, some degree of clinical improvement had followed treatment; yet within a few months there was evidence of a relentless decline. It seemed as if a policy of 'ringing the changes' had been attempted by employing combinations of various types of therapy in an apparently desperate attempt to save the patient's sanity.

Choice of the particular therapy used did not apparently rest on a particular cluster of clinical features. In general the basis of therapy seemed to be random and could not be compared from patient to patient. Increasing dementia and other central nervous system signs in a large proportion of these patients suggested that factors beyond the control of available therapy were operating.

\section{Summary}

A clinical survey was made of 43 patients with general paralysis of the insane, most of whom had been hospitalized for between 10 and 20 years. Most of the patients were in the 40 to 50 years age group on admission and had been suffering from clinically recognizable symptoms of GPI for 2 to 4 years before coming to the hospital.

The ultimate degree of incapacity and the progressive nature of the signs and symptoms at three separate stages of the illness are evaluated. Some sex-differences were found which had not been noted in previous studies. The types of treatments employed and the effect on blood and cerebrospinal fluid studies are described. The possible effect of ageing or of persistence of Treponema pallidum within the central nervous system after treatment and the likelihood that this will give rise to an increased incidence of certain symptoms is indicated. The value of routine screening for syphilis in mental hospitals is discussed.

Our thanks are due to the consultant medical staff and nursing staff of Middlewood Hospital, Sheffield, for their kind co-operation, without which such a study could not have been undertaken. One of us (K. D.-B.) is indebted to Drs N. L. Gittleson and E. Gemmell for making available study time to carry out this research. We are also indebted to Prof. E. Stengel (Emeritus Professor of Psychiatry, University of Sheffield) for helpful criticism in the early stages of the work. We are particularly grateful to Dr. R. S. Morton (Consultant Venereologist, United 
Sheffield Hospitals) for his unfailing support and encouragement.

\section{References}

ARENTSEN, K., and Welner, J. (1955) Acta psychiat. neurol. scand., 30, 529

Banks, G. D. (1968) Brit. F. Psychiat., 114, 113

BARNetT, C. W. (1955) Stanford med. Bull., 13, 234

Bostroem, A. (1930) In 'Handbuch der Geisteskrankheiten,' ed. O. Bumke, vol. 8, p. 165. Springer, Berlin

Brit. med. f. (1969) Leader, 1, 67 (Facts about venereal disease)

Collart, P., Borel, L. J., and Durel, P. (1962) Ann. Inst. Pasteur (Lille), 102, 596, 693, 953

$\longrightarrow,-\longrightarrow$ (1964) Brit. F. vener. Dis., 40, 81

Dattner, B., Carmichael, D. M., De Mello, L., and Thomas, E. W. (1952) Amer. F. Syph., 36, 179

-, Thomas, E. W., and De Mello, L. (1951) $\mathcal{F}$. vener. Dis. Inform., 32, 33

DAWSON-BUTTERWORTH, K. (1967a) Brit. med. F., 2, 510

- (1967b) Practitioner, 199, 68

- (1968) Brit. F. clin. Pract., 22, 471

- (1969) Ibid., 23, 125

Dewhurst, K. (1969) Brit. F. Psychiat., 115, 31

Ehrentheil, O. F., and Muench, H. (1959) f.chron. Dis., 9,41

Gager, W. E., Israel, C. W., and Smith, J. Lawton (1968) Brit. f. vener. Dis., 44, 277

Guthe, T. E. (1965) 'Research Reviews and Clinical Trials, 1964-65', ed. D. J. E. L. Carrick, p. 162-170. Medica News, London

hahn, R. D., Cutler, J. C., Curtis, A. C., Gammon, G., Heyman, A., Johnwick, E., Stokes, J. H., Solomon, H., Thomas, E., Timberlake, W., WebSter, B., and Gleeson, G. A. (1956) A.M.A. Arch. Derm., 74, 355, 367

-, Webster, B., Weickhardt, G., Thomas, E., Timberlake, W., Solomon, H., Stokes, J. H., Moore, J. E., Heyman, A., Gammon, G., Gleeson, G. A., Curtis, A. C., and Cutler, J. C. (1959) A.M.A. Arch. Neurol., 81, 557

'Henderson and Gillespie's Textbook of Psychiatry' (1962) 9th ed., revised by D. Henderson and I. R. C. Batchelor, pp. 374-389. Oxford University Press, London

HEATHFIELD, K. W. G. (1968) Brit. med. F., 1, 765

HuRIEZ, C., AGACHE, P., and Souilliart, F. (1962) Bull. Soc. méd. Hôp. Paris, 113 (4 sér., 77), 466

Joffe, R., BLACK, M. M., and Floyd, M. (1968) Brit. med.F., 1, 211

Kaplan, B. I., Ryan, J., Thomas, E., Cutler, J. C., and JENKINs, K. H. (1958) f. chron. Dis., 7, 300,

$\longrightarrow,-, \ldots$, - - , and JONES, O. (1958) Ibid., 7, 312

KalZ, F., and ScotT, A. (1958) Acta. derm.-venereol. (Stockh.), 38, 155
Kopp, H., and RaAschou-Nielsen, W. (1956) Ibid., 36, 482

LAIRD, S. M. (1962) Brit. med. F., 1, 524

LEVY, B. (1968) Ibid., 2, 491

Lewis, B. I. (1950) Amer. F. Syph., 34, 534

LIU, M. C. (1960). F. ment. Sci., 106, 1082

MaHONEY, J. F., ARNOLD, R. C., and HARRIS, A. (1943) F. vener. Dis. Inform., 24, 355

$\longrightarrow,-\longrightarrow$ (1949) Ibid., 30, 350

Malykin, P. Ja., Sokolin, A. I., and Vasil'ev, T. V. (1958) Vestn. Derm. Vener., 32, No 2, p. 36

OrbáN, T., and LAZARovits, L. (1956) Wien. med. Wschr., 106, 377

O'Brien, J. F., Smith, C. A., and Fisherkeller, M. A. (1955) Brit. F. vener. Dis., 31, 74

POWER, T. D. (1930) F. ment. Sci., 76, 524

Pritchard, J. G., Mechie, A. M., McHugh, J. G., and Boot, P. A. (1967) Brit. F. vener. dis., 43, 18

RAASCHOU-NIELSEN, W., and Kopp, H. (1957) Acta derm.-venereol. (Stockh.), 37, 446

Smith, J. Lawton, and IsRael, C. W. (1968). Brit. f. vener. Dis., 44, 109

STEEL, R. (1960). Lancet, 1, 121

TeMPSKI, J., OlsZeWSKA, Z., and HeYko-Porebski, J. (1957) Przegl. Derm. Wener., 44, 39

TurNer, T. B., Hardy, P. H., and Newman, B. (1969) Brit. F. vener. Dis., 45, 183

VARMa, L. P. (1952) Indian F. Neurol. Psychiat., 3, 141

VuRdelja, N., Vucković, S., and Kapamadzija, B. (1961) Arch. Psychiat. Nervenkr., 202, 177

Willcox, R. R. (1967) Brit. F. clin. Pract., 21, 165

WILNER, E., and BRody, I. A. (1968) Lancet, 2, 1370

WodNIANSKY, P. (1963) Z. Haut u. Geschl.Kr., 35, 65

Revue de cas de paralysies générales hospitalisés

SOMMAIRE

On a fait une enquête sur 43 cas de PG dont la majorité avait été hospitalisés entre dix et vingt ans. La plupart des malades avaient 40 à 50 ans au moment de l'admission et avaient présenté des symptômes cliniques de PG deux à quatre ans avant leur admission.

Le niveau final d'incapacité et la nature progressive des signes et symptômes ont été évalués à trois étapes différentes de la maladie. Quelques différences selon le sexe ont été trouvées qui n'avaient pas été notées dans les études précédentes. On décrit les types de traitement employés et leurs effets sur le sang ou le LCR. On indique le rôle que pourraient jouer des Treponema pallida vieillissants ou persistants dans le système nerveux central après traitement, et la possibilité que ceci puisse entraîner une augmentation de certains symptômes. On discute la valeur des examens de routine pour la découverte de la syphilis dans les hôpitaux psychiatriques. 